\title{
Political corporate social responsibility in authoritarian contexts
}

\author{
Anna-Lena Maier \\ University of Hamburg, Von-Melle-Park 9, \\ 20146 Hamburg, Germany \\ Correspondence: \\ A Maier, University of Hamburg, Von-Melle- \\ Park 9, 20146 Hamburg, Germany \\ e-mail: anna-lena.maier@uni-hamburg.de
}

\begin{abstract}
Political CSR emphasizes the need for the democratic governance of business conduct through public deliberation, and expects multinational enterprises (MNEs) to contribute to self-regulation and public goods provision to fill the gaps left by unwilling or unable governments. In the under-researched context of autocracies, however, political pluralism and participation are severely limited, which confronts MNEs with limited governance spaces for such activities. In this article, I deconstruct the assumptions on political-institutional context prevalent in political CSR and IB research on political and CSR activities of MNEs. Drawing on political science literature on state power and authoritarianism, I reconstruct political CSR in the political-institutional context of authoritarianism, using different autocracies across the globe as illustrative examples. I elucidate the boundaries and room for responsible business policies in autocracies drawing on a framework I developed that distinguishes between high- and low-capacity autocracies. My framework implies that MNEs face constraints in autocracies with regard to public deliberation and self-regulation, while there is considerable room for public goods provision. Finally, I explain why the normative desirability for the former two is high, whereas the normative desirability of public goods provision through MNEs in authoritarian contexts is lower given its implications for stabilization of autocratic rule.

Journal of International Business Policy (2021) 4, 476-495.

https://doi.org/ | 0. I057/s422 I4-020-00085-3
\end{abstract}

Keywords: corporate social responsibility; business-government relations; governance; political economy; institutional environment

The online version of this article is available Open Access

\section{INTRODUCTION}

In this conceptual paper, I discuss how a political-institutional context of authoritarianism constrains the room for responsible business conduct of multinational enterprises (MNEs). I focus on using Middle Eastern autocracies as illustrative examples, but also refer to other regional contexts where appropriate. Responsible business conduct in this paper refers to MNEs pursuing political corporate social responsibility (political CSR) by engaging in public deliberation, self-regulation, and public goods provision to fill the
Received: 4 December 2019

Revised: 9 November 2020

Accepted: 17 November 2020

Online publication date: 17 January 2021 
gaps left by "weak" or "unwilling" governments (Scherer \& Palazzo, 2007, 2011; Scherer, Palazzo, \& Seidl, 2013; Scherer, Rasche, Palazzo, \& Spicer, 2016). The corporate engagement in public deliberation can manifest itself as participation in multistakeholder initiatives (MSIs) that involve a multitude of state and non-state actors seeking to address issues of public concern, such as environmental pollution or problematic labor conditions (Huber \& Schormair, 2019). Through these deliberative and self-regulatory initiatives, they assume "political co-responsibility" (Scherer \& Palazzo, 2007: 1109), thus turning into political actors (Scherer et al., 2016). In autocracies, governments and ruling elites assume powerful roles that significantly constrain the room for political CSR's central prescriptions, and thus also for corporate activities studied in international business (IB), e.g., MNEs' partnerships with societal actors (Kolk \& Lenfant, 2015a). In autocracies, political participation and public deliberation face repression through state authorities, and business is shaped through a particular political economy with a clear dominance of ruling elites (Ayubi, 1995; Hertog, Luciani, \& Valeri, 2013; Linz, 2000; Perlmutter, 1981; Schlumberger, 2007). Several indexes underscore the need to address these issues in autocracies, where forced labor mixed with weak government responses is prevalent (see, e.g., Walk Free Foundation, 2018), or corruption is widespread (Transparency International, 2018).

Context matters, and extant research has discussed the context-dependence of (political) CSR (Dentchev, Haezendonck, \& van Balen, 2016; Jamali \& Carroll, 2017; Örtenblad, 2016; Wang, Tong, Takeuchi, \& George, 2016). In different political-institutional contexts, different formal and informal rules of the game constrain and shape human interaction (North, 2017) and the room and boundaries for responsible business. Whether an MNE is able or willing to engage in self-regulation and governance is "contingent, at least in part, upon the national systems of government-business relations present in its home market" (Detomasi, 2015: 685), but also depends on the politicalinstitutional particularities of the host country. However, the political-institutional context forming the background condition for MNEs taking on quasi-governmental roles (see, e.g., Wickert, 2014) is usually assumed to be a context of weak or limited statehood (Scherer \& Palazzo, 2011; Scherer, Palazzo, \& Matten, 2014). Recent research on the role of governments in the governance of business conduct has called for studies of the "various ways that governments continue to support, steer, or counteract corporate engagement with public interest issues" (Eberlein, 2019: 1140), but does not explicitly account for the politicalinstitutional context in terms of regime types (on the continuum of democracy - autocracy), either. It thereby often assumes the "Western", capitalist and more or less democratic state to be the universal default model informing discussions surrounding the implications of government roles for (political) CSR (Adegbite, Amaeshi, \& Nakajima, 2013; Egri \& Ralston, 2008; Jamali \& Carroll, 2017; Jamali \& Neville, 2011). The rich body of the IB literature equally examines different political activities and roles of MNEs in challenging host-country contexts focusing on fragile state or developing country contexts (Adegbite et al., 2013; Jamali \& Karam, 2018; Kolk, 2016; Oetzel \& Getz, 2012), or contexts characterized by weak institutions or institutional voids (Doh, Rodrigues, Saka-Helmhout, \& Makhija, 2017; Sidki Darendeli \& Hill, 2016).

IB research building on the Varieties of Capitalism (e.g., Hall \& Soskice, 2001) and National Business Systems (Whitley, 1999) literature has continuously been refining the existing frameworks of government involvement in the economy and the corresponding business-state relationships. In their recent Varieties of Institutional Systems framework, Fainshmidt et al. (2018), for instance, distinguish four types of states: developmental, predatory, regulatory, and welfare, whereas a developmental state, for example, can also be predatory. Predatory then refers to states that are being governed by "elites who monopolize power through the use of opaque decision-making procedures, weak institutions, and a lack of market competition" (Carney \& Witt, 2014: 550).

It is not entirely clear, however, how governmental power limits the room for political and CSR activities of MNEs in these contexts. The contextual sensitivity of such conceptualizations notwithstanding, I thus see value in applying an interdisciplinary approach to better account for state power, and go beyond single measurements of state involvement. For example, a dominant role of the state (state direct dominance) is measured through the prevalence of state ownership and government expenditure as a percentage of GDP (Fainshmidt et al., 2018: 312). I argue that the interdisciplinary approach I pursue in this paper provides an analytical macro-structure that contributes to a theoretically enriched understanding of how power 
materializes in predatory (or authoritarian) states in a way that shapes the room for (political) CSR.

Whether one addresses state power, or the power of MNEs (Ruggie, 2018), in a political-institutional context of democracy or authoritarianism holds different theoretical and managerial implications. An MNE's efforts to self-regulate will face different institutional constraints in an autocracy than in a democracy, and IB scholars need to understand the resulting potential interconnections and interactions between MNEs and different local contexts (Lundan, 2018). While the room for the central political CSR activities of public deliberation and self-regulation is severely constrained given the unchecked power of governments, their normative desirability is high, which is why we should not disregard them completely based on the contextual challenges MNEs will inevitably face when attempting to implement them. Given their status as powerful actors in international business (Ruggie, 2018), MNEs need to explore how they can overcome or mitigate contextually induced boundaries for political CSR, at least if we assume that human rights violations and exploitation are unacceptable phenomena in any given context. This leads to the guiding research question of this paper: How can political CSR theorizing be applied to authoritarian contexts?

To answer this question, and to derive some key implications for MNEs' responsible business policies in autocracies, I combine the Habermasianinspired stream of political CSR research and the IB literature on political and CSR activities of MNEs with insights of political science research on statehood and authoritarianism. More precisely, the paper proceeds as follows: I deconstruct political CSR's core assumptions on political-institutional context, focusing on the three central dimensions of governance model, role of law, and democracy. I focus on political CSR, as it is a widely discussed concept of rising prominence, and because its critical deconstruction promises to contribute to a refinement of IB theory on political and CSR activities of MNEs. I present central IB research on political and CSR activities of MNEs in challenging host-country contexts before summarizing some crucial conceptual commonalities and differences between the corresponding political CSR and IB literature. Drawing on political science literature on authoritarianism and "the" state, I subsequently explain why repressive executive branches are not a sufficient indicator of state power, and why regime type is not synonymous with state strength (Ezrow
\& Frantz, 2013: 17), which indicates that the growing body of literature on the persistence of the state in the governance of business conduct (see, e.g., Schrempf-Stirling, 2018; Wood \& Wright, 2015) could also benefit from further contextualization.

To do so, I draw on and adapt Charles Tilly's crude typology of regimes (Tilly, 2003, 2007), which groups regimes in a matrix resulting from the dimensions of low to high government capacity and low to high democracy, and thus distinguishes the crude types of high- and low-capacity autocracies and, respectively, democracies. Then, I explore and reconstruct political CSR in the politicalinstitutional context of authoritarianism, using mostly Middle Eastern autocracies as illustrative examples, while focusing on the three central dimensions of governance, role of law, and democracy. Finally, I derive managerial implications for responsible business policies in autocracies.

I seek to make three contributions: First, I contribute to the development of political CSR by critically deconstructing its central assumptions on political-institutional context, especially with regard to the notions of state power and regime type, to thus, second, refine IB theory on political and CSR activities of MNEs in authoritarian host countries. Third, and by reconstructing political CSR in the under-researched political-institutional context of authoritarianism, I develop a framework, based on Tilly's crude typology of regimes, deriving concrete implications for responsible business policies of MNEs in autocracies. As current developments in the U.S. and Europe foreshadow, the theoretical insights derived from this deconstruction and reconstruction in the context of authoritarianism might eventually have to be applied to current strongholds of democracy.

\section{DECONSTRUCTING CONTEXTUAL ASSUMPTIONS OF POLITICAL CSR AND IB RESEARCH ON POLITICAL AND CSR ACTIVITIES OF MNES}

The political activities and strategies MNEs use to navigate the challenging political-institutional contexts of their host countries as well as their antecedents, outcomes, and variations have been at the center of inquiry of IB scholars for decades (Kolk, 2016; Kolk \& van Tulder, 2010; Pisani, Kourula, Kolk, \& Meijer, 2017). The IB literature has been informed considerably by research on nonmarket strategies (NMS) of MNEs, which serve 
to manage the political-institutional context, or nonmarket environment, they operate in (Akbar \& Kisilowski, 2015; Baron, 1995; Boddewyn, 2003; Doh, Lawton, \& Rajwani, 2012; Doh, McGuire, \& Ozaki, 2015; Dorobantu, Kaul, \& Zelner, 2017; Frynas, Child, \& Tarba, 2017; Mellahi, Frynas, Sun, \& Siegel, 2016; Wrona \& Sinzig, 2018). Nonmarket strategy research comprises examinations of a variety of political activities, e.g., investigations of corporate political Activity (CPA) (Lawton, McGuire, \& Rajwani, 2013; Rudy \& Johnson, 2019; Schuler, Rehbein, \& Green, 2019) such as lobbying governments for preferential policy outcomes (Baysinger, 1984; Lux, Crook, \& Woehr, 2011; Mellahi et al., 2016), international CSR activities such as self-regulation or collaboration with nongovernmental organizations (NGOs) (Christmann \& Taylor, 2006; Detomasi, 2015; Kourula, 2010), and activities covered in research on business and peace (Kolk \& Lenfant, 2015b, 2016; Oetzel \& Getz, 2012) or corporate diplomacy (Westermann-Behaylo, Rehbein, \& Fort, 2015). IB research is often particularly interested in the implications of political activities and CSR for corporate performance and competitive advantage (see, e.g., Mellahi et al., 2016). The political activity of MNEs has thus also been examined in connection with strategic CSR activities (Buckley, Doh, \& Benischke, 2017; den Hond, Rehbein, Bakker, \& Kooijmans-van Lankveld, 2014; Frynas et al., 2017; Morsing \& Roepstorff, 2015). Recent work has inquired how firms seek to establish close business-state relationships to obtain access to critical resources (Doh et al., 2017: 298), and how firms may benefit from positive reputation effects in their CPA in connection with CSR activities (den Hond et al., 2014; Rehbein \& Schuler, 2015).

Not all of these political activities of firms necessarily have to be interpreted as political CSR, while it certainly remains true that the theoretical and normative underpinnings of political CSR research go beyond the Habermasian foundation Scherer et al. propose (see, critically, Frynas \& Stephens, 2015). Building on Habermasian deliberative democracy (1996), political CSR as proposed by Scherer and Palazzo particularly expects MNEs to engage in public deliberation to ensure moral legitimacy and accountability (Gilbert \& Rasche, 2008; Gilbert, Rasche, \& Waddock, 2011; Palazzo \& Scherer, 2006; Scherer et al., 2013; Suchman, 1995). According to political CSR, governments and MNEs, often in interaction with civil society actors, jointly contribute to the governance of business conduct (Scherer et al., 2014; Scherer \& Palazzo, 2007, 2011). Firms are expected to assume political co-responsibility by filling regulatory gaps left by unable or unwilling governments "by engaging in public deliberations, collective decisions, and the provision of public goods or the restriction of public bads" (Scherer et al., 2016: 276). Through their self-regulation efforts, they become "authors of rules with public impact" (Scherer \& Palazzo, 2007: 1098), rather than being mere addressees of government regulations. As political actors, MNEs in particular contribute to the responsible governance of business conduct by providing public goods such as education or improved labor conditions, or limiting public bads such as corruption or inequality (Scherer et al., 2016: 276). This emphasis on deliberative, communicative processes is what distinguishes political CSR from other IB concepts exploring political and CSR activities of MNEs (Mena \& Palazzo, 2012; Palazzo \& Scherer, 2006; Scherer et al., 2013; 2014, 2016; Scherer \& Palazzo, $2007,2011)$. Since it is also an approach the authors have indicated to be of particular relevance to authoritarian host-country contexts of international business activity (Scherer et al., 2016), political CSR in its deliberation-focused sense forms the central point of departure of my conceptual (and critical) reflections.

Political CSR builds on a set of assumptions on political-institutional context that need to be inquired more critically, especially since these assumptions are also prevalent in the IB literature, which generally takes great interest in varieties of business-government relations (Blumentritt, 2003; Doh et al., 2012; Luo \& Zhao, 2013; Peng \& Luo, 2000; Wrona \& Sinzig, 2018). Before discussing and problematizing core assumptions on state power and the interrelated dimension of regime type (on a continuum of democracy - autocracy), I briefly outline political CSR's three dimensions of governance model, role of law, and democracy, as they most explicitly refer to political-institutional context.

\section{Three Dimensions of Political-Institutional Context: Governance Model, Role of Law, Democracy}

In order to deconstruct political CSR's and the IB literature's core assumptions on political-institutional context systematically, I follow the lines of discussion introduced by Scherer and Palazzo (2011), taking into account their expanded research agenda (Scherer et al., 2016). The three central 
dimensions of political-institutional context - governance model, role of law, and democracy - that Scherer and Palazzo discuss extensively in their almost classical 2011 paper are decisive preconditions for the three normative prescriptions of Habermasian-inspired political CSR for MNEs: public deliberation, self-regulation, and public goods provision. Therefore, they are of particular relevance for my analysis, and structure the following discussion accordingly. This structure is summarized in Table 1 . Table 1 also comprises the extension of political CSR and political activities of MNEs in autocracies derived from my efforts of a contextually sensitive deconstruction and reconstruction. The presentation of the literature should be understood as observed tendencies of the respective literatures, rather than universal truth claims.

Table 1 Political CSR and political and CSR activities of MNEs in authoritarian contexts

Political and CSR activities of MNEs in Political CSR

IB
Political CSR and political and CSR activities of MNEs in a context of authoritarianism

\section{Governance}

model

Main political State, but MNEs and NGOs

actor

increasingly in focus

Locus and

mode of

governance

Separation of political and economic

spheres

Role of law

Mode of

regulation

Dominant rules

Delegation to third parties

Democracy

Model of democracy

Concept of politics

Power of MNEs

\footnotetext{
Democratic Derived from political system, control and inclusion of (salient) stakeholders legitimacy of firms
} hierarchy, but global/multilevel heterarchic forms of governance increasingly in focus political sphere

Governmental regulation and selfregulation when facing state fragility/weak institutions/ institutional voids

Formal rules and "hard law" plus informal rules and "soft law"

Increasingly observable

Variety of political systems, leaning towards liberal democracy

Power politics

Weakening of state power leads to increased power of MNEs
State, civil society, and firms

Emphasis on national governance and

High, but efforts of MNEs to influence Low
Heterarchic and global/multilevel governance and intergovernmental initiatives

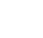

Self-regulation when facing state fragility/weak institutions/ institutional voids

Informal rules and "soft law"

Often

Deliberative democracy

Discursive politics

Weakening of state power leads to increased power (and obligation) of MNEs

Corporate activities subject to democratic control, expansive inclusion of stakeholders (emphasis on civil society, NGOs)
State/authoritarian government and informal actors with ties to the ruler(s), e.g., influential merchants, tribal or religious representatives, ...

National governance and hierarchy; intergovernmental initiatives mainly when it comes to regulation relevant for foreign direct investment

Low: dominance of state-owned firms, privately owned firms equally dominated by ruler(s); high: little influence of MNEs on public regulation

Governmental regulation; selfregulation mostly contingent upon governmental priorities

Formal rules and "hard law" applied and enforced selectively/arbitrarily, plus informal rules Seldom

Non: autocracy

Authoritarian power politics

Governments/rulers as powerful actors with regard to repression, but mixed picture with regard to government capacity

Derived from authoritarian government, firms are depoliticized in the sense that they cannot be authors of public regulation, and politicized in the sense that they are expected to contribute to the autocracy's stability 
The first dimension of political-institutional context of particular relevance to my analysis refers to the underlying governance model. According to Scherer and Palazzo, public authorities and state power are increasingly weakened, and the state is no longer the main political actor. In the IB literature, the main political actor, especially with regard to regulation, continues to be the state, who is mostly influenced or lobbied by MNEs (Boddewyn, 2016; de Villa, Rajwani, Lawton, \& Mellahi, 2018; Mellahi et al., 2016), but not replaced. However, MNEs collaborating with NGOs and other nongovernmental actors have increasingly come into focus (Boddewyn, 2016; Boddewyn \& Buckley, 2017; see, e.g., Boddewyn \& Doh, 2011; Doh et al., 2015; Doh et al., 2017; Vachani, Doh, \& Teegen, 2009). In the course of globalization processes, networks of actors including MNEs and civil society organizations shape the governance of business conduct, e.g., within the framework of multi-stakeholder initiatives (MSIs) (Mena \& Palazzo, 2012). This leads to an assumption of increasingly heterarchical modes of governance in political CSR research, and shifts the locus of governance from the national to a global or intergovernmental level. In IB research, national governance both within the host and home country tends to be emphasized, which corresponds to an emphasis on hierarchy. Recently, global and multilevel governance has received increasing attention (Barkemeyer, Preuss, \& Lee, 2015; Kolk \& van Tulder, 2010; Pisani et al., 2017), thus also shifting the focus further towards heterarchy.

The separation of the political and economic spheres is commonly understood as low in political CSR: both private and public actors contribute to regulation, rather than leaving such activities in the realm of the state alone (Scherer \& Palazzo, 2011: 908). While research widely discussed in IB has also paid attention to multi-actor regulatory efforts (Gilbert \& Rasche, 2008; Gond, Kang, \& Moon, 2011; Kolk, 2016), it still leans towards an assumption of a high degree of separation of political and economic spheres. This separation is also expressed in the literature's focus on how MNEs try to influence the political sphere to e.g., change regulation in their favor (Akbar \& Kisilowski, 2015; Kamasak, James, \& Yavuz, 2019; Rajwani \& Liedong, 2015), rather than aiming at a division of labor.

The second dimension refers to the general role of law that influences whether and how MNEs are best understood as mere addressees or (co-)authors of governmental regulation: MNEs proactively contribute to filling governance gaps, thus changing the mode of regulation from governmental to selfregulation. As indicated above, IB research leans more towards a focus on governmental regulation and, where this is absent, institutional voids that need to be addressed through self-regulation (Amaeshi, Adegbite, \& Rajwani, 2016; Doh et al., 2017) and other (nonmarket) strategies such as internalization, while even holding the potential to provide opportunities for MNEs (Khanna \& Palepu, 2010). Regarding the dominant rules guiding business policies, political CSR is based on informal rules and "soft law", rather than relying on formal regulation issued by governments. This shift emphasizes voluntary action of MNEs, i.e., a low level of obligation (Scherer \& Palazzo, 2011: 912), and a correspondingly lower precision of rules given that they often emerge in deliberative processes involving a multitude of actors. IB research on political and CSR activities of MNEs provides little specification on the level of obligation and precision of rules, but this depends on the focus of the respective work, especially with regard to government regulation. Furthermore, in its institutional theory tradition, IB research has highlighted the role of informal institutions shaping the structure and strategies, as well as the space for political activities, of MNEs (Cantwell, Dunning, \& Lundan, 2010; Doh et al., 2017). Concerning the delegation of political activity to third parties, e.g., firms, political CSR assumes that non-state actors will often step in to fill regulatory gaps, rather than relying on nation-state regulation. In IB research, a tendency towards an increasing delegation of political activities to third parties is observable (Mellahi et al., 2016; Pisani et al., 2017; Wrona \& Sinzig, 2018).

Finally, the third dimension of interest refers to the model of democracy. Political CSR is based on a model of deliberative democracy, which allows firms, governments, and civil society actors to enter into public deliberation and thus produce regulation. Discursive politics in political CSR subject corporate activities to democratic control. This leads to a commitment to democratic modes of corporate governance that even extends the inclusion of stakeholders other than shareholders also of interest to IB scholarship. Power politics are thus replaced by discursive politics (Scherer \& Palazzo, 2011: 908). IB research addresses a variety of political-institutional systems (Henisz \& Zelner, 2005; Marquis \& Qian, 2014), but especially with 
regard to home-country institutions shaping the room for CSR activities, the model of democracy assumed most often is one of liberal democracy (Egri \& Ralston, 2008; Jamali \& Karam, 2018; Jamali, Karam, Yin, \& Soundararajan, 2017; Pisani et al., 2017), and the emphasis on activities such as $\mathrm{CPA}$ at least provide an argument for associating it with a concept of power politics, which, of course, can be debated. Corresponding to this is another dimension I added, the power of MNEs. In IB research, the weakening of state power in the course of globalization leads to an increased power of MNEs - which are already powerful in several ways (Ruggie, 2018). This observation is shared in political CSR, which widely assumes the same tendency, but also goes beyond that observation in assigning them an enlarged set of obligations and responsibilities. In the next section, I elucidate the underlying assumptions on state power informing such analyses.

\section{Strong States, Weak States - Dominant Assumptions on State Power}

As indicated in the previous section, the two bodies of literature share several assumptions regarding state power that vary in degree rather than principle, e.g., with regard to a stronger emphasis of political CSR on MNEs as actors replacing or supplementing governments. These assumptions need to be deconstructed to expand and refine IB theory on political and CSR activities of MNEs, and to be able to answer recent calls to further study the role of power and power dynamics (Child, 2018; Clegg, 2010; Clegg, Voss, \& Tardios, 2018; Jamali et al., 2017). As stated above, political CSR is mostly seen as a response to fragile statehood (Kobrin, 2009; Matten \& Crane, 2005; Scherer et al., 2014; Scherer \& Palazzo, 2007, 2011). The role of governments in shaping governance spaces (Kourula, Moon, Salles-Djelic, \& Wickert, 2019), i.e., the room for corporate attempts at self-regulation and related activities, continues to be a central theme in current debates (see, e.g., Detomasi, 2015; Eberlein, 2019; Gond et al., 2011; Knudsen \& Brown, 2015; Schrempf-Stirling, 2018). Authors referring to the persistence of "the" state (see, e.g., Eberlein, 2019; Kourula et al., 2019; Schrempf-Stirling, 2018; Wood \& Wright, 2015) commonly do not elaborate on what actually constitutes state strength or capacity in general or in a specific political-institutional context, e.g., authoritarianism, and thus do not explicitly state the boundary conditions for the generalizability of their theorization. Recent calls for a more focused analysis of business-government interactions (Hamann, 2019; Knudsen \& Moon, 2017) tend to focus on different roles of governments, but do not take explicit account of the political-institutional context of these interactions beyond referring to that "the" state reasserts its power. Furthermore, potential differences of a materialization of state power in a democracy versus in an autocracy remain unaccounted for (Schneider \& Scherer, 2019; Schrempf-Stirling, 2018).

The same is true for the greatest part of IB research on political and CSR activities of MNEs in challenging political-institutional contexts. When, for example, authors like Doh et al. (2017) emphasize how firms can respond to institutional voids by e.g., establishing "close business-state relationships to facilitate access to otherwise scarce resources" (Doh et al., 2017: 298), those calls need to be founded on a clear understanding of potential roles of the governmental counterpart constraining or enabling corresponding activities. This hints at the need of IB research to examine and discuss the "boundary conditions of current CSR understandings" (Amaeshi et al., 2016: 148), and entails critically reflecting upon notions of weak institutions or fragile statehood prevalent in the IB literature on political and CSR activities of MNEs (Adegbite et al., 2013; Amaeshi et al., 2016; Kolk \& Lenfant, 2010, 2015a, 2015b; Sidki Darendeli \& Hill, 2016). In particular, an explicit and in-depth conceptual differentiation of regime types in connection with state power is lacking. While some authors do refer to authoritarianism explicitly (e.g., Jia, Shi, \& Wang, 2018), they mostly do not distinguish between regime type and government capacity. This presents a promising avenue for scholarly enquiry since an autocracy may be weak in one aspect (for example, public goods provision) and powerful in another aspect (for example, repression of civil society), thus highlighting the need to distinguish the categories of state power and regime type.

An MNE will approach the government of what it understands as a "weak state" differently than that of what it sees as a "strong state", and will face different constraints in an autocracy than in a democracy. Limitations with regard to a theorization of state power thus also affect the IB literature on political and CSR activities of MNEs in terms of an assessment of the latter's power. Ruggie (2018), for example, rightfully argues that power is inherently relational, and highlights that the power and 
authority of state and MNE coexist. He does not differentiate regime types and thus optimistically argues that MNEs can, for example, force suppliers in host states to adhere to social and environmental standards (Ruggie, 2018: 327). While this is true for specific political-institutional host country contexts, MNEs will inevitably face considerable constraints in consolidated autocracies. This illustrates how an engagement with the political science literature on state power and authoritarianism may be a promising avenue of further theorizing of MNE power.

How, then, can the political science literature on authoritarianism and a critical discussion of the contextual assumptions of political CSR contribute to the IB literature on political and CSR activities of MNEs, and what are the corresponding implications for MNEs' responsible business policies in autocracies? There are various approaches to conceptualizing and measuring state power, mostly referred to as state strength or capacity (see, e.g., Cingolani, Thomsson, \& Crombrugghe, 2015). State power and its implications have been discussed in the political science and related literature for decades and from various perspectives (Krasner, 1984), all of which I cannot account for in this article. Furthermore, a "definitive conception of what makes for a capable state is elusive because the specific characteristics and activities of states that promote larger social goals change over time and differ across national experiences" (Hall \& Ikenberry, 1996: 96).

The first generic and rather important distinction that needs to be made refers to regime type (on a continuum of autocracy - democracy) versus government capacity. An authoritarian state that, for example, more or less successfully represses civil society demands for public deliberation, can be described as powerful in the sense that it does not have to undertake "routine, institutionalized negotiation with civil society groups" (Mann, 1986: 113), as would be the case in a democracy. This capacity for repression prevalent in autocracies, however, does not necessarily indicate a corresponding degree of government capacity with regard to the state's "bureaucratic, administrative, legal, and fiscal capacity" (Savoia \& Sen, 2015: 442443). This illustrates that repression is not a sufficient indicator of state power, just as a lack of regulation does not necessarily indicate a somehow diminished state capacity: "state capacity and regime type are conceptually distinct" (Knutsen, 2013: 2). At the same time, state "weakness can take different forms" (Campbell \& Hall, 2015: 64), and a repressive state can lack state capacity in areas such as economic development or public goods provision.

To make this more concrete, I draw on the related but more hands-on typology of crude regime types introduced by Charles Tilly (2003, 2007), which illustrates this consequential differentiation of particular relevance to both the political CSR and the IB literature on political and CSR activities of MNEs, and has considerably shaped how political science scholars think about state power. Figure 1 is my adaptation of Tilly's typology of crude regimes and also summarizes the basic implications of crude regime types for responsible management I derived from my analyses, which I will discuss in detail later. In Tilly's original typology, he refers to autocracy as "undemocratic" (Tilly, 2003: 39, 2007). To remain consistent with the terminology used throughout this paper, I adapted the denotation accordingly.

On the vertical axis, political regimes are located based on government or state capacity, i.e., the "extent of government agents' control over resources, activities, and populations located routinely within the government's territorial jurisdiction" (Tilly, 2003: 38). The horizontal axis of democracy refers to what Tilly also termed "protected consultation" (ibid). This refers to the extent to which the population is involved in political decision-making, how equal access to agents of government is distributed, the degree to which the government is controlled by political participants, and the extent to which the latter are protected from arbitrary action by governmental agents. The resulting typology of high-capacity autocracy, lowcapacity autocracy, high-capacity democracy, and low-capacity democracy contains, on average, descriptions, and countries within a single quadrant can differ considerably with regard to degree of government capacity or democracy (Tilly, 2007). In the quadrant of low-capacity autocracy, for example, Egypt would, based on established governance indexes such as the World Bank's "Worldwide Governance Indicators", probably have to be positioned at the top of the quadrant, while Somalia as another example for a low-capacity autocracy would be found at the bottom. Against this background, it becomes obvious that state power and regime type should not be conflated. In the following, and going beyond this general distinction, I draw on empirically informed political science research to reconstruct how these general 

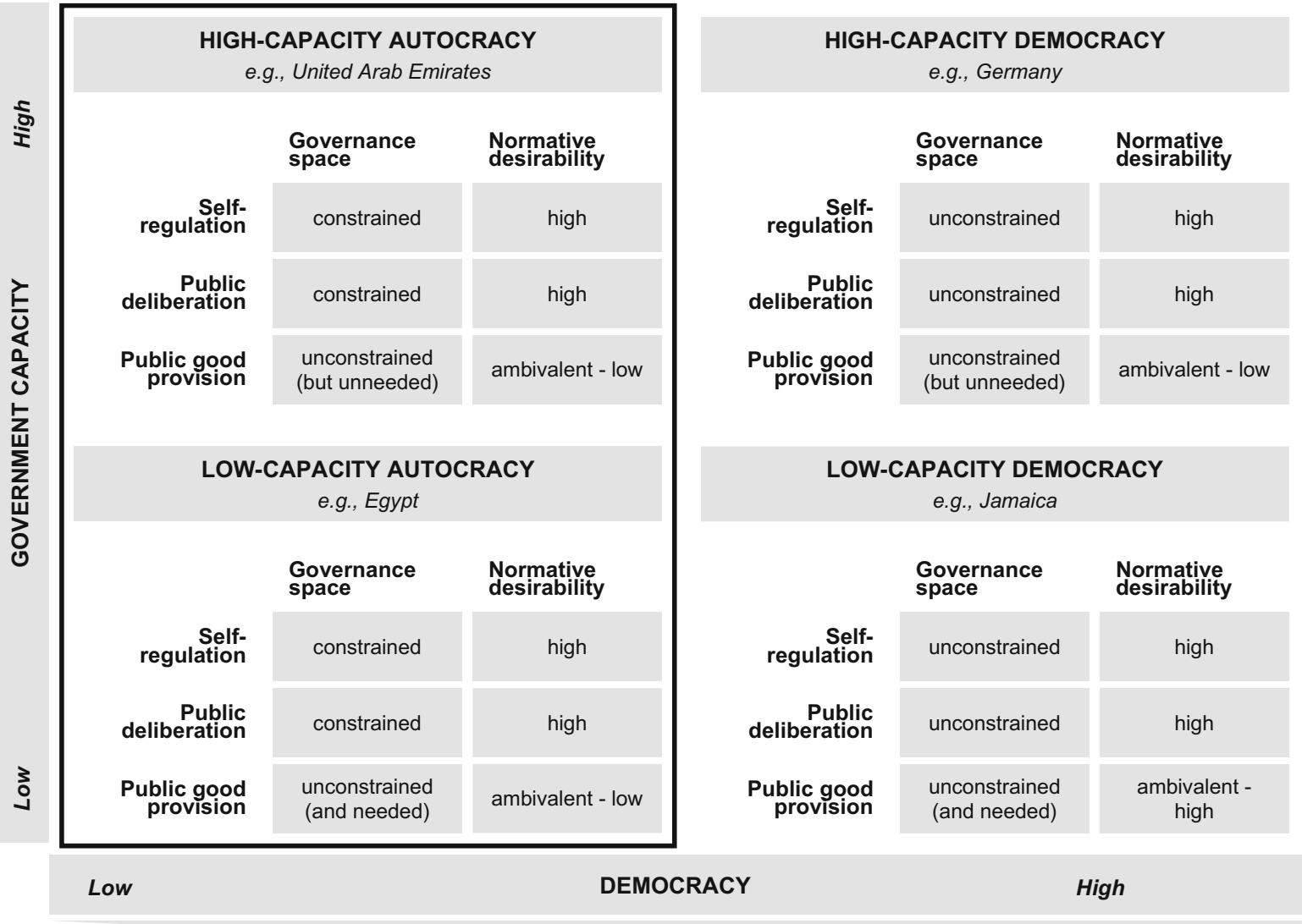

LOW-CAPACITY DEMOCRACY

e.g., Jamaica

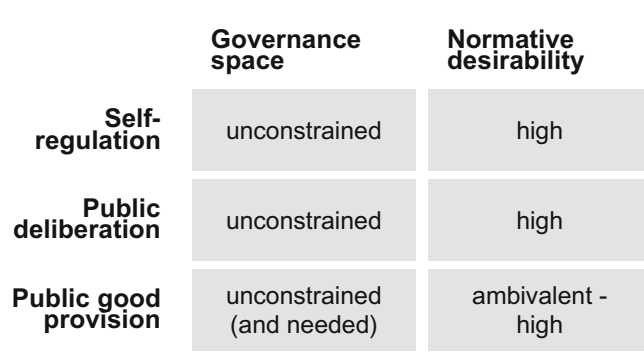

Figure 1 Implications of crude regime types for responsible management (autocracies highlighted), own figure adapted from Tilly (2003, 2007).

distinctions materialize in autocracies. I also use authoritative IB studies on business in authoritarian contexts to provide additional illustrative examples that support my arguments.

\section{RECONSTRUCTING POLITICAL CSR IN THE POLITICAL-INSTITUTIONAL CONTEXT OF AUTHORITARIANISM}

To be able to assess the room and boundaries for MNEs pursuing their political CSR in the context of authoritarianism, we have to reach a more nuanced understanding of the role of governmental institutions in an autocracy. In general, authoritarianism refers to all forms of undemocratic rule. The ruling elites of autocracies limit pluralism and political participation, and the power of the executive lacks popular control. Governments are not accountable to their citizens (Linz, 2000), and constantly seek to "coopt, subdue, or eliminate all sources of political power outside the state system"
(Perlmutter, 1981: 26), if necessary, by violent coercion or repression (Josua \& Edel, 2014).

I use Middle Eastern autocracies as illustrative examples, and refer to other autocracies where appropriate. Certain observations are generalizable to autocracies in other geographical regions. The states of the Middle East differ with regard to their political foundations (e.g., presidential system vs. monarchy), degree of authoritarianism (e.g., fully consolidated autocracy vs. close to hybrid regime e.g., the United Arab Emirates vs. Iraq) and the corresponding degree of repression (higher in Saudi Arabia than, for instance, in Jordan), the importance of oil wealth for the economy (oil vs. nonoil), or government capacity (e.g., the degree to which and under which conditions they provide public goods to their citizens) (for a detailed review, see Jamali, Jain, Samara, \& Zoghbi, 2020). In order to provide sufficiently generalizable explanations, however, I continue to focus on commonalities, particularly the overall political-institutional fabric 
of authoritarianism prevalent in the region (Jebnoun, Kia, \& Kirk, 2015).

Due to their demonstrated ability to employ repressive means, autocracies are often described as powerful. However, as Tilly's typology I adapted illustrates in more concrete terms, "it is an error to equate the strength or autonomy of the state with the ability of state elites to ignore other social actors or to impose their will in any simple manner on society" (Hall \& Ikenberry, 1996: 95). Empirically, autocracies do not necessarily realize state goals most effectively. While a security apparatus can be "brutally effective", other government agencies may at the same time "routinely mishandle simple tasks like processing visa applications or licensing small businesses" (Fukuyama, 2004: 22), thus displaying limited government capacity. Table 1, whose first two columns I have referred to in detail above, summarizes the crucial differences in political-institutional context, the last column highlighting central contextual dimensions shaping the limitations and potential for political CSR and political and CSR activities of MNEs in autocracies. In the following, I again discuss these focusing on the governance model, the role of law, and democracy.

\section{The Governance Model in Autocracies}

In autocracies, the state (or rather: the ruling elite) continues to be the main political actor. With regard to public goods provision, historically e.g., social security ("waqf") or solidarity ("al-takaful"), throughout the "Arab world" were provided "by civil society and not the central power", central power here referring to the longtime Arab equivalent to the Western notion of the state (Hafez, 2014: 426). Within the framework of Western notions of state strength, the substitution of state agencies by non-state actors such as Islamic charities in terms of public goods provision can be seen as proof for limited government capacity, also because the state's legitimacy may decrease in the eyes of its populace (Mühlberger, 2014: 17-18). Given intensified diversification pressures, Arab Gulf autocracies like Oman require a re-organization of the labor market and subsequent education and vocational training initiatives (Minnee, Shanka, Taylor, \& Handley, 2013). The region's state visions that lay out economic development plans accordingly emphasize the role of private sector contributions to such reforms. CSR programs of MNEs can be expected to address the interest of an authoritarian government in local capacity building and knowledge transfer in other regional contexts, too, as research on the energy sector in Kazakhstan (Orazgaliyev, 2018) or authoritarian capitalism in China (Witt \& Redding, 2014) illustrates.

Furthermore, many Middle Eastern autocracies like the Arab Gulf states, also described as rentier states (Beblawi, 1987; Gray, 2011), generate government revenues not via extractive capacity vis-àvis "society", but via petroleum rents, which "has substantially lessened the reliance of many Middle Eastern governments on their own populations" (Anderson, 1987: 9). Other countries, like Jordan, cannot rely on oil wealth, but have similar rent distribution mechanisms in place, as their economy and the corresponding taxation mechanisms rely upon foreign aid and workers' remittances as oilrich Arab Gulf autocracies rely on oil and gas rents (Peters \& Moore, 2009). In times of abundant oil revenues or rents generated through e.g., foreign aid, the governments of resource-rich autocracies commonly provide their citizens with health care, education, and social welfare in general (Kropf, 2016: 18). During a fiscal crisis (Schwarz, 2008), however, this may change, and lead to waves of privatization and an outsourcing of government functions to MNEs. Rather than a sign of limited or declining government capacity, this may also be interpreted as a sign for the contrary, as "the ability to act flexibly - to intervene, withdraw, reform or abstain - is at the heart of state capacity" (Hall \& Ikenberry, 1996: 97).

In conclusion, the governance model in autocracies is shaped by the authoritarian government as the main political actor, as well as informal actors close to the ruling elite, e.g., influential merchants (Almezaini, 2013; Azoulay, 2013); the locus of governance is national in key areas central to authoritarian rule (e.g., labor laws). When areas of governance affect foreign direct investment (FDI), governance is more likely to be selectively opened to e.g., intergovernmental initiatives (see, e.g., Escribà-Folch, 2017; Hertog, 2010). Research on Egypt has also shown that the Egyptian authoritarian government pushes for CSR beyond traditional philanthropy to align with prestigious initiatives such as the United Nations Global Compact (UNGC) or with stock market sustainability requirements to enhance global competitiveness and attract FDI (Kamel \& Awadallah, 2017; LagoardeSegot, 2011).

The mode of governance is correspondingly hierarchic. However, given that "most regimes in 
the region, whether old or new, face a potential fiscal and employment crisis, unfolding against the background of heightened popular expectations and weak administrative apparatuses" (Hertog, 2013: 2), the role of local firms and need for business capacities will likely expand, possibly changing the dynamic. Economic rationality dominates insofar as corporate agency is viewed through a lens of usefulness for the autocratic ruling elite, and domesticated insofar as political survival is prioritized over economic sustainability of a corporate entity. In state-owned enterprises (SOEs) in particular, decisions are mainly made on personal or political rather than business grounds, e.g., along the principle of wastah ("privileged contact which brings gain") (Niblock, 2007: 152). SOEs are central players in the global economy (Bruton, Peng, Ahlstrom, Stan, \& Xu, 2015; CuervoCazurra, Inkpen, Musacchio, \& Ramaswamy, 2014), and have been shown to be used by authoritarian governments to pursue nationalistic agendas (Clegg et al., 2018). They play an important role in autocracies in general (Sprenger, 2008) and the Middle East in particular (OECD, 2013), and MNEs entering these markets are typically required to partner with them in joint ventures. Finally, the separation of political and economic spheres with regard to both domestic and foreign companies is low in the sense that firms owned by ruling elites dominate the economic ecosystem, and domestic companies in private ownership are under equally strong influence of, and interwoven with, the autocratic rulers (Hertog et al., 2013). MNEs face a comparable amount of institutional pressure and governmental interference, but have even less influence on public regulation than domestic companies whose representatives are more likely to participate in informal meetings (e.g., the majlis) shaping policy and regulatory outcomes.

\section{The Role of Law in Autocracies}

Drawing on other authoritative works (e.g., Evans, 1995), authors who examine the contextual background conditions for CSR activities of MNEs in such contexts often emphasize the importance (and contingency) of forging political connections with powerful elites to reduce uncertainty regarding rules and regulation (Haveman, Jia, Shi, \& Wang, 2017). In connection to that, the dominant mode of regulation in autocracies is governmental regulation (see, e.g., Niblock, 2007), rather than self-regulation through MNEs. Autocracies are characterized by formal rules and 'hard law' being applied selectively. Hard law exists, and the corresponding level of obligation is high, e.g., with regard to anti-corruption policies. However, its enforcement depends on informal power structures specific to the authoritarian political-institutional context. Furthermore, since informal rules implicitly shape the boundary conditions for business conduct, there is a low precision of rules, which leaves discretion to the authoritarian government, as well as room for arbitrary maneuvers. This could be observed in the "Saudi Purge" or anti-corruption crackdown ordered by Crown Prince Mohammad Bin Salman, which also led to the arrest of AlWaleed bin Talal, the member of the Saudi royal family with considerable shares in Western firms such as Citigroup or Twitter (Hubbard, Kirkpatrick, Kelly, \& Mazzetti, 11 March, 2018).

Where there is voluntary action of MNEs and domestic companies, it is predominantly aligned with governmental priorities. At the same time, authoritarian governments throughout the region leave regulatory or implementation gaps with regard to e.g., workers' rights, which, other than in the standard cases of political CSR, are commonly not filled by MNEs (Beinin, 2010). A delegation to third parties of governance activities happens rarely. Even if there are efforts led by Western NGOs and foreign donor organizations directed at, for example, the promotion of good governance in this authoritarian context, the process quickly becomes flawed, as "networks of privilege" develop within the given donor system, as could be observed in the case of Western donors in Egypt (Zovighian, 2013: 196) corresponding to the neo-patrimonial structures in the host country.

\section{The Model of Democracy in Autocracies}

In an autocracy, demands for public deliberation, although effectively countered by the authoritarian government and ruler(s), are not completely absent. They are, however, subject to the authoritarian concept of politics, which can be described as power politics taken to the extreme, whose overarching goal is regime survival (Rivlin, 2009: 293). Even elections, when taking place, predominantly serve as a means to consolidate authoritarian power (Bölme, 2015: 7). Furthermore, freedom of speech is severely restricted (Møller \& Skaaning, 2013), which holds implications for discursive forms of stakeholder involvement. He and Warren (2011) have correspondingly shown for the autocracy of China how a combination of non-inclusive power and deliberation leads to the phenomenon of 
authoritarian deliberation: deliberation involving a multitude of state and non-state actors may thus take place in an autocracy. It will, however, likely fail most commonly accepted legitimacy criteria (see, e.g., Mena \& Palazzo, 2012) given the institutional setup, and even facilitate "authoritarian power sharing" between the authoritarian ruler(s) and their allies (Svolik, 2012: 87).

While discursive politics in political CSR subject corporate activities to democratic control, i.e., leading to a democratic mode of corporate governance, in an authoritarian context, the legitimacy of firms is mainly derived from the authoritarian government's priorities (see, e.g., Hertog et al., 2013). At the same time, as I discuss further in the implications sections, civil society stakeholders are rarely able to exert pressures for CSR adoption, especially in resource-rich autocracies. Therefore, as has been shown for the case of the oil industry in Angola, MNEs mainly enter partnerships with NGOs (where existent) to improve chances of winning contracts and licenses (Wiig \& Kolstad, 2010), while leaving governance issues unaddressed. An authoritarian government's survival correspondingly not only depends on repression, but also (and crucially so) on co-optation (Köllner \& Kailitz, 2013) of other relevant actors such as firms and business elites (Sassoon, 2016). As Middle Eastern governments are under immense pressure to improve living standards and create jobs (Joyce, 2015: 51), the latter will likely be expected to provide for these much-needed public goods. Firms are thus depoliticized in the sense that they can hardly be authors of public regulation, and politicized in the sense that they are expected to contribute to the autocracy's stability. This is supported by recent advances of Middle Eastern governments to push for CSR that is aligned with governmental interests using formal law (UAE) and state visions (e.g., Kuwait or Saudi Arabia). Therefore, firms are not democratically controlled, and they derive their legitimacy from the respective authoritarian ruler or elite. The mode of corporate governance in this context can then be described as primarily shareholder-oriented, in the sense that the authoritarian ruler(s) are the main shareholders, either directly via governmental ownership, or indirectly in privately owned firms via their ties and influence (see, e.g., Gause III, 2018).

\section{IMPLICATIONS FOR RESPONSIBLE BUSINESS POLICIES OF MNES IN AUTOCRACIES}

What do these contextual deviations from the standard cases of political CSR and IB research on political and CSR activities of MNEs imply for deliberation, self-regulation, and public goods provision? I summarize the key implications for responsible international business policies in Fig. 1, which contains a framework for an exploration of contextually sensitive responsible business policies in autocracies. The framework distinguishes governance spaces, i.e., the room for the respective political CSR activity, and their normative desirability. The autocracies are highlighted with a frame. Since responsible business policies of MNEs in democracies are not the focus of this article, I will refer to them only briefly. All quadrants refer to host-country contexts. The examples provided in the single quadrants are placed there based on a consultation of relevant and established indexes such as the World Bank's World Governance Indicators, Polity IV, or IMF data. These examples, however, are intended to describe tendencies rather than definitive positions, and are subject to debate.

\section{Deliberation in Autocracies}

MNEs are powerful actors with considerable resources (see, e.g., Levy, Reinecke, \& Manning, 2016). However, managers seeking to participate in free public deliberation with e.g., civil society stakeholders face considerable challenges in autocracies. In a high-capacity democracy like Germany, which is characterized by a relatively high government capacity and a relatively high degree of democracy, MNEs would face few constraints when attempting to engage in public deliberation given the overall democratic institutional fabric. The same would be observable in a low-capacity democracy like Jamaica, where freedom of speech and assembly and other relevant political rights are similarly protected. In both high- and low-capacity autocracies, however, political pluralism and participation and the lack of protected consultation (Tilly, 2003) referred to above are severely limited, and the governance space for deliberation is constrained. The prospects for the inclusion of civil society actors, e.g., local communities or NGOs, into corporate democratic decision-making are rather poor. There might be variation across autocracies depending on where on the continuum of democracy - autocracy they are. Deliberation in the 
sense of political CSR in a fully consolidated autocracy like the United Arab Emirates will be close to impossible, but a much more realistic expectation in a transitioning country moving towards a hybrid regime, e.g., Iraq or Jordan. In the baseline scenario, however, it remains true that if MNEs attempted to push for discursive and genuinely inclusive formats, the authoritarian governmental counterpart would retaliate by e.g., cutting diplomatic ties or denying further access to key decision makers, thus also stopping current business transactions or hindering market access.

When deliberation takes place in an authoritarian context, managers need to be aware that it follows different rules. A study by King et al. (2013) has thus shown that the Chinese censorship program carefully monitors social media regardless of the content of the posts - rather, it is designed to target and inhibit social mobilization or collective action, whatever the underlying issue may be. This indicates the limits for MNE managers to communicatively engage with civil society in authoritarian contexts, especially since civil society is neither particularly independent from governmental interests, nor sufficiently organized (Carney \& Witt, 2014; Zhao, Park, \& Zhou, 2014).

Nevertheless, political CSR is not naïve in assuming that all political decision-making, especially in this context, should be exposed to public deliberation. Rather, "small steps of constant improvement and transformation of real democratic processes and institutions" (Scherer \& Palazzo, 2007: 1107) are suggested as a way for firms to ensure their moral legitimacy (Suchman, 1995). Given their overall power, MNEs can still raise critical issues such as stakeholder engagement in talks with governmental counterparts, e.g., when their top management attends assemblies with privileged access to local elites such as the regular majlis held at rulers' palaces. As MNEs have been shown to engage in CSR activities in the comparable context of Angola mainly to win contracts and licenses, and merely reflect governmental priorities (Wiig \& Kolstad, 2010), I am not too optimistic regarding the use of this potential instrument to advance deliberative formats. Since MNEs are, often by law, required to partner with Middle Eastern SOEs, they will necessarily be subjugated to the host government's interests and way of (not) addressing ethical issues, which poses another challenge to responsible business conduct. However, the repression of public deliberation should not be confused with a popular lack of interest in it.
To the contrary, at least when referring to Arab autocracies, "democratic elements are not absent from Arab culture" (Sawani, 2014: 351) at all, and MNEs should find ways to address them adequately. Managers may increase their room for maneuver in this regard through emphasizing the reputation effects and international prestige of sustainable business policies (Nalband \& Al-Amri, 2013).

\section{Self-Regulation in Autocracies}

Both in high- and low-capacity democracies, the governance spaces for MNEs engaging in self-regulation are widely unconstrained, as long as they complement rather than attempt to replace the host-country's regulation. The need for self-regulation might be greater in a democracy with a relatively diminished government capacity. Given the overall democratic institutional structure, the respective governments are unlikely to constrain MNEs' efforts to go beyond local regulations. As I have discussed above, managers in autocracies need to establish close connections to political powerholders to e.g., obtain clarity regarding regulation, which, in turn, reduces uncertainty (Haveman et al., 2017). This need to engage with current and prospective (Sidki Darendeli \& Hill, 2016) powerholders to strengthen their political capabilities in the challenging context of autocracies illustrates the limited prospects for self-regulation efforts that are undertaken relatively independent of governmental interests and priorities (Li, Peng, \& Macaulay, 2013). In the light of the multiple ways ruling elites in autocracies and their interests are interwoven in business, as well as their dominance in regulatory activities and overall repressiveness, one must conclude that independent corporate regulation efforts face severe constraints both in highand low-capacity autocracies. Governance gaps or rather most often a selective enforcement, e.g., with regard to labor rights or corruption, notwithstanding, the ruling elites remain the main political actor. While MNEs which are, for example, engaged in large-scale construction projects in the Arab Gulf states, may exert a certain influence on some operative levels, for example the level of wages for construction workers, they will be restricted by the authoritarian state on other operative levels, for example with regard to the workers' freedom of movement. The closer an issue is to every-day business operations or current governmental priorities, and the further away from being deemed "political", the more room do managers have for 
self-regulation efforts. In several Arab Gulf states, managers thus have considerably more leeway regarding environmental protection policies, as such an engagement is in compliance with current governmental sustainability commitments (e.g., Jamali et al., 2020).

Furthermore, self-regulation will be a more realistic expectation in low-capacity autocracies that, for example, also depend on foreign aid or are in the process of transitioning into a hybrid regime. The tendency, however, is that MNEs continue to be mere addressees of government regulation. They will have more leverage if they address central governmental interests and priorities of relevance to regime survival through their business activities. For example, the German DAX 30 firms Siemens and SAP have rolled out extensive education and training programs across the Middle East, which are explicitly linked to their CSR policies and growth plans, and are an exact reflection of current governmental priorities. Finally, firms will not necessarily act as "stewards of the public interest when governments are absent or fail" (Eberlein, 2019: 1126) when doing business in autocracies. Self-regulatory efforts of MNEs, however, are normatively desirable, e.g., with regard to workers' rights. Further empirical research should thus explore ways in which MNEs try to either extend their role in this regard, or approach these structures opportunistically.

\section{Public Goods Provision in Autocracies}

In all four regime types, public goods provision is widely unconstrained. In high-capacity democracies and autocracies, however, the provision of goods such as healthcare or education is not necessarily needed in the sense that the government commonly does not leave such a gap for MNEs to fill, while such gaps tend to exist in lowcapacity regimes, irrespective of degree of democracy. Whether public goods provision through MNEs is normatively desirable in democratic contexts is subject to a debate that cannot be resolved in this paper. Depending on the need for it, it can be described as ambivalent, with a tendency towards high normative desirability in low-capacity democracies and low desirability in high-capacity democracies.

As explained above, ruling elites both in highand low-capacity autocracies have increasingly started to push foreign firms for public goods provision (see, e.g., Kingdom of Saudi Arabia, 2015). Much like the Arab Gulf autocracies, Russia presents another case where firms need to expect to be pressured to provide social welfare when the state is unable to do so (Crotty, 2016). Managers of MNEs doing business in autocracies should be prepared to be confronted with governmental demands that directly affect the contents and scope of their local CSR policies, irrespective of their headquarters' standardized guidelines and codes of conduct. In this context, however, MNEs do not simply fall victim to circumstances. Rather, they should recognize the relationship- and political capability-building potential of their company's CSR policies, as these can serve to signal partnership with the government, for example with regard to education and training. Ethical considerations regarding such partnerships with autocracies notwithstanding, managers should emphasize those contributions publicly and in personal talks with key members of the ruling elites to enhance firm visibility and legitimacy in the eyes of the host-country government.

With regard to the more theoretical discussion on state power, this holds at least two theoretical implications. First, and maybe even counterintuitively, an authoritarian government may assert its power through the outsourcing and privatization of governance and public goods provision, rather than necessarily demonstrating a lack of state capacity. As Eberlein (2019) notes, the privatization of government functions generally does not have to result from a somehow diminished state power, but can be an outcome of political choice, and thus underline the government's central capacity to withdraw or intervene flexibly (Hall \& Ikenberry, 1996). Several autocracies remain stable as they rely on an implicit social contract that involves the neopatrimonial provision of social welfare in exchange for political compliance - this model, however, only works as long as there are enough resources to be allocated (Schwarz, 2008: 607-609). By choosing to outsource, for example, education and training to MNEs, authoritarian governments can avoid political instability in times of e.g., fiscal crises.

Second, in such a political-institutional context, corporate contributions to education are better understood as economic interest-based strategies focusing on the governmental counterpart to e.g., secure resources and access (Wiig \& Kolstad, 2010), rather than the "societal good". Such a selfless focus on the latter, however, is what Habermasian-inspired political CSR tends to presuppose. Especially in autocracies, the underlying motivations of such activities should rather be understood as 
interwoven with strategic considerations both on the corporate and governmental side. Future research should investigate the corresponding overlapping of political CSR and the nonmarket strategy literature, which has begun to explore how firms strategically use CSR activities to manage and navigate challenging political-institutional hostcountry contexts (Buckley et al., 2017; Mellahi et al., 2016).

There also is a need to normatively discuss the corporate provision of e.g., education in these political-institutional contexts. Access to resources in general and education in particular is often determined through distributive logics of neo-patrimonial patronage (Migdal, 2003), which increases the authoritarian regime's capacity to "penetrate society and ensure compliance" (Bach, 2012: 29). When MNEs set up education programs under these conditions, they may unintentionally contribute to the persistence of authoritarian rule. Therefore, while there is considerable room for corporate public goods provision, its normative desirability is rather low.

Finally, democratic home-country governments ought to take these complexities into account by balancing their export and international trade promotion activities with ethical considerations. One way to do so could be to incentivize responsible business conduct via connecting policies and instruments of foreign trade promotion, such as state-sponsored credit insurance for international business, to responsibility criteria. The corresponding foreign trade laws would then require defining responsibility criteria that truly capture the potential negative externalities of firm activity, rather than taking, e.g., education and training activities as a sufficient indicator of responsible business conduct. Especially when FDI from a democratic home country into an authoritarian host country is concerned, which typically involves a high degree of intergovernmental coordination, democratic home-country governments should raise issues such as stakeholder involvement in talks with their authoritarian counterparts.

\section{CONCLUSION}

In order to take the "political" in political CSR and IB research on political activities of MNEs seriously, assumptions on the political-institutional context need to be stated more explicitly. Since state power is a central constitutive factor for the political engagement of firms, there is a need to better understand and conceptualize it. I have used my thorough de- and reconstruction of central assumptions on political-institutional context dominant in both literatures to refine political CSR and thus also contribute to the IB literature on political and CSR activities of MNEs. Using my framework for responsible business in autocracies adapted from Tilly's crude typology of regimes, I derive implications for MNEs' responsible business policies in autocracies. While MNEs face severe constraints in both high- and low-capacity autocracies with regard to public deliberation and self-regulation, there is considerable room for public goods provision. Strikingly, however, the normative desirability for the former two central pillars of political CSR is high, whereas the normative desirability of public goods provision through MNEs in authoritarian contexts is lower given its implications for stabilization of autocratic rule. Authoritarianism is a political-institutional context setting considerable boundaries for deliberative processes that include civil society actors. Nevertheless, on a normative level, the principles of deliberative democracy political CSR draws on do not have to be disregarded completely when facing a politicalinstitutional context of authoritarianism. MNEs could at least amplify the voices of stakeholders commonly ignored in these contexts, e.g., workers, and use their respective corporate sphere of influence. It would be interesting to explore the scope of these spheres of influence in sub-contexts. While the challenge might be even greater in consolidated autocracies that are rich in natural resources (e.g., Saudi Arabia or the United Arab Emirates), the room for a corporate mitigation of the negative effects of the political institutional context of authoritarianism might be considerably greater in a less autocratic country like Jordan, which also heavily depends on foreign funding.

This paper is not without limitations. Any analysis of the power of the state is strongly dependent on definitions and understandings of the state itself. Questions on definitive conceptualizations of the state have been at the center of scholarly debates for decades (Mitchell, 1991; Nettl, 1968) and cannot be resolved in this paper. As there are uncountable ways "the" state may look like, this paper has to focus on selected dimensions that promise at least some clarifying insights, e.g., with regard to the prevalent tendency to confuse repression with strength. My own use of concepts, such as "the state", is shaped through Western discourses, and I am aware that when applied to non-Western 
contexts, these concepts and their underlying epistemology (see, e.g., Hafez, 2014) carry their own biases and assumptions with them. Throughout the "Arab world", historically Arab state formation itself has to be seen in a context of Western imperialism, or European colonialism, whose administrative remains have influenced Arab bureaucracies profoundly (see, e.g., Anderson, 1987). All discussions, mine included, on the role of governments and "the state" need to take these pitfalls and potential reproductions of hegemonic discourses into account.

Finally, political CSR rests on the assumption "that actors bear responsibility for problems of structural injustice to which they contribute by their actions and [...] from which they themselves benefit" (Scherer \& Palazzo, 2011: 913). In its forward-looking, solution-oriented approach, and once informed with a higher degree of contextsensitivity, political CSR may still indicate ways in which firms can avoid becoming socially irresponsible actors in autocracies, and inspire future IB research accordingly. Just because MNEs increasingly face authoritarian contexts, in which noninclusive governments dominate the governance of business conduct, they should not stop reflecting upon possible responsible pathways. Future research should empirically investigate the boundary conditions for responsible management in

\section{REFERENCES}

Adegbite, E., Amaeshi, K., \& Nakajima, C. 2013. Multiple influences on corporate governance practice in Nigeria: Agents, strategies and implications. International Business Review, 22(3): 524-538.

Akbar, Y. H., \& Kisilowski, M. 2015. Managerial agency, risk, and strategic posture: Nonmarket strategies in the transitional core and periphery. International Business Review, 24(6): 984-996.

Almezaini, K. 2013. Private sector actors in the UAE and their role in the process of economic and political reform. In S. Hertog, G. Luciani, \& M. Valeri (Eds), Business politics in the Middle East: 43-66. London, United Kingdom: Hurst \& Company.

Amaeshi, K., Adegbite, E., \& Rajwani, T. 2016. Corporate social responsibility in challenging and non-enabling institutional contexts: Do institutional voids matter? Journal of Business Ethics, 134(1): 135-153.

Anderson, L. 1987. The state in the Middle East and North Africa. Comparative Politics, 20(1): 1-18.

Ayubi, N. N. 1995. Over-stating the Arab state: Politics and society in the Middle East. London: Tauris.

Azoulay, R. 2013. The politics of Shi'i merchants in Kuwait. In S. Hertog, G. Luciani, \& M. Valeri (Eds), Business politics in the Middle East: 677-699). London, United Kingdom: Hurst \& Company.

Bach, D. C. 2012. Patrimonialism and neopatrimonialism: Comparative receptions and transcriptions. In D. Bach, \& M. under-researched political-institutional contexts while paying particular attention to contextual specificities. Further exploring the political and CSR activities of MNEs under the umbrella of nonmarket strategy research also promises to be a fruitful avenue of scholarly enquiry.

\section{ACKNOWLEDGEMENTS}

I did not receive any financial or research assistance for this manuscript. An early version of it has been presented at the Annual Conference of the Society for Business Ethics in Chicago, USA, in August 2018. I am grateful for feedback provided by Miguel Alzola, Fordham University, USA, who discussed the manuscript within the framework of the Society for Business Ethic's Emerging Scholars program. I am also very grateful for the exceptionally developmental and constructive feedback provided by the three anonymous reviewers, as well as Anne Hoekman's and Rob van Tulder's patience and support throughout the review process.

\section{FUNDING}

Open Access funding enabled and organized by Projekt DEAL.
Gazibo (Eds), Neopatrimonialism in Africa and beyond: 25-45. New York: Routledge.

Barkemeyer, R., Preuss, L., \& Lee, L. 2015. On the effectiveness of private transnational governance regimes - evaluating corporate sustainability reporting according to the Global Reporting Initiative. Journal of World Business, 50(2): 312-325.

Baron, D. P. 1995. Integrated strategy: market and nonmarket components. California Management Review, 37(2), 47-65.

Baysinger, B. D. 1984. Domain Maintenance as an Objective of Business Political Activity: An Expanded Typology. Academy of Management Review, 9(2), 248-258.

Beblawi, H. 1987. The rentier state in the Arab world. In $\mathrm{H}$. Beblawi \& G. Luciani (Eds), The rentier state: 49-62). London: Croom Helm.

Beinin, J. 2010. The struggle for worker rights in Egypt. Washington, D.C.: Solidarity Center.

Blumentritt, T. P. 2003. Foreign subsidiaries' government affairs activities. Business \& Society, 42(2), 202-233.

Boddewyn, J. J. 2003. Understanding and advancing the concept of 'nonmarket'. Business \& Society, 42(3), 297-327.

Boddewyn, J. J. 2016. International business-government relations research 1945-2015: Concepts, typologies, theories and methodologies. Journal of World Business, 51(1): 10-22.

Boddewyn, J. J., \& Buckley, P. J. 2017. Integrating social and political strategies as forms of reciprocal exchange into the analysis of corporate governance modes. British Journal of Management, 28(4): 575-588. 
Boddewyn, J., \& Doh, J. 2011. Global strategy and the collaboration of MNEs, NGOs, and governments for the provisioning of collective goods in emerging markets. Global Strategy Journal, 1(3-4): 345-361.

Bölme, S. M. 2015. The roots of authoritarianism in the Middle East. In J. Karakoç (Ed.), Authoritarianism in the Middle East. Before and After the Arab Uprisings: 7-37. Basingstoke, Hampshire, New York: Palgrave Macmillan.

Bruton, G. D., Peng, M. W., Ahlstrom, D., Stan, C., \& Xu, K. 2015. State-owned enterprises around the world as hybrid organizations. Academy of Management Perspectives, 29(1): 92-114.

Buckley, P. J., Doh, J. P., \& Benischke, M. H. 2017. Towards a renaissance in international business research? Big questions, grand challenges, and the future of IB scholarship. Journal of International Business Studies, 48(9): 1045-1064.

Campbell, J. L., \& Hall, J. A. 2015. The World of states. London: Bloomsbury Academic.

Cantwell, J., Dunning, J. H., \& Lundan, S. M. 2010. An evolutionary approach to understanding international business activity: The co-evolution of MNEs and the institutional environment. Journal of International Business Studies, 41(4): 567-586.

Carney, R. W., \& Witt, M. A. 2014. The role of the state in Asian business systems. In M. A. Witt \& G. Redding (Eds), The Oxford Handbook of Asian business systems: 538-560 (1st ed.). Oxford: Oxford University Press.

Child, J. 2018. Should your IB research deal with power? Academy of International Business Insights, 18(2): 3-6.

Christmann, P., \& Taylor, G. 2006. Firm self-regulation through international certifiable standards: Determinants of symbolic versus substantive implementation. Journal of International Business Studies, 37(6): 863-878.

Cingolani, L., Thomsson, K., \& de Crombrugghe, D. 2015. Minding Weber more than ever? The impacts of state capacity and bureaucratic autonomy on development goals. World Development, 72:191-207.

Clegg, S. 2010. The state, power, and agency: Missing in action in Institutional Theory? Journal of Management Inquiry, 19(1): 4-13.

Clegg, L. J., Voss, H., \& Tardios, J. A. 2018. The autocratic advantage: internationalization of state-owned multinationals. Journal of World Business, 53(5): 668-681.

Crotty, J. 2016. Corporate social responsibility in the Russian Federation: A contextualized approach. Business \& Society, 55(6): 825-853

Cuervo-Cazurra, A., Inkpen, A., Musacchio, A., \& Ramaswamy, K. 2014. Governments as owners: state-owned multinational companies. Journal of International Business Studies, 45(8): 919-942.

de Villa, M. A., Rajwani, T., Lawton, T. C., \& Mellahi, K. 2018. To engage or not to engage with host governments: Corporate political activity and host country political risk. Global Strategy Journal, 23(2): 438.

den Hond, F., Rehbein, K. A., de Bakker, F. G. A., \& Kooijmansvan Lankveld, H. 2014. Playing on two chessboards: Reputation effects between corporate social responsibility (CSR) and corporate political activity (CPA). Journal of Management Studies, 51(5): 790-813.

Dentchev, N. A., Haezendonck, E., \& van Balen, M. 2016. The role of governments in the business and society debate. Business \& Society, 56(4): 527-544.

Detomasi, D. 2015. The multinational corporation as a political actor: 'Varieties of capitalism' revisited. Journal of Business Ethics, 128(3): 685-700.

Doh, J. P., Lawton, T. C., \& Rajwani, T. 2012. Advancing nonmarket strategy research: Institutional perspectives in a changing world. Academy of Management Perspectives, 26(3): 22-39.
Doh, J., McGuire, S., \& Ozaki, T. 2015. Global governance and international nonmarket strategies: Introduction to the special issue. Journal of World Business, 50(2): 256-261.

Doh, J., Rodrigues, S., Saka-Helmhout, A., \& Makhija, M. 2017. International business responses to institutional voids. Journal of International Business Studies, 48(3): 293-307.

Dorobantu, S., Kaul, A., \& Zelner, B. 2017. Nonmarket strategy research through the lens of new institutional economics: An integrative review and future directions. Strategic Management Journal, 38(1): 114-140.

Eberlein, B. 2019. Who fills the global governance gap? Rethinking the roles of business and government in global governance. Organization Studies, 40(8), 1125-1145.

Egri, C. P. \& Ralston, D. A. 2008. Corporate responsibility: A review of international management research from 1998 to 2007. Journal of International Management, 14(4): 319-339.

Escribà-Folch, A. 2017. Foreign direct investment and the risk of regime transition in autocracies. Democratization, 24(1): 6180.

Evans, P. B. 1995. Embedded autonomy: States and industrial transformation. Princeton, N.J: Princeton University Press.

Ezrow, N. M., \& Frantz, E. 2013. Failed states and institutional decay: Understanding instability and poverty in the developing world. London: Bloomsbury Publishing.

Fainshmidt, S., Judge, W. Q., Aguilera, R. V., \& Smith, A. 2018. Varieties of institutional systems: A contextual taxonomy of understudied countries. Journal of World Business, 53(3): 307322.

Frynas, J. G., Child, J., \& Tarba, S. Y. 2017. Non-market social and political strategies - new integrative approaches and interdisciplinary borrowings. British Journal of Management, 28(4): 559-574.

Frynas, J. G., \& Stephens, S. 2015. Political corporate social responsibility: Reviewing theories and setting new agendas. International Journal of Management Reviews, 17(4): 483-509.

Fukuyama, F. 2004. The imperative of state-building. Journal of democracy, 15(2): 17-31.

Gause III, F. G. 2018. Saudi regime stability and challenges. In M. Al-Rasheed (Ed.), Salman's legacy. The dilemmas of a new era in Saudi Arabia: 31-43. London, United Kingdom: C. Hurst $\&$ Co. (Publishers) Ltd.

Gilbert, D. U., \& Rasche, A. 2008. Opportunities and problems of standardized ethics initiatives - a stakeholder theory perspective. Journal of Business Ethics, 82(3): 755-773.

Gilbert, D. U., Rasche, A., \& Waddock, S. 2011. Accountability in a global economy. Business Ethics Quarterly, 21(1): 23-44.

Gond, 1.-P., Kang, N., \& Moon, J. 2011. The government of selfregulation: On the comparative dynamics of corporate social responsibility. Economy and Society, 40(4): 640-671.

Gray, M. 2011. A theory of "late rentierism" in the Arab states of the Gulf (Occasional Paper no. 7). Qatar: Georgetown University School of Foreign Service, Center for International and Regional Studies.

Habermas, J. 1996. Between facts and norms: contributions to a discourse theory of law and democracy. Cambridge, MA: MIT Press.

Hafez, Z. 2014. Some Western concepts through Arab eyes: Toward a new Arab epistemology. Contemporary Arab Affairs, 7(3): 421-436

Hall, J. A., \& Ikenberry, G. J. 1996. The state. Milton Keynes: Open University Press.

Hall, P. A., \& Soskice, D. W. (Eds). 2001. Varieties of capitalism: The institutional foundations of comparative advantage. Oxford, England, New York: Oxford University Press.

Hamann, R. 2019. Dynamic de-responsibilization in businessgovernment interactions. Organization Studies, 40(8): 11931215.

Haveman, H. A., Jia, N., Shi, J., \& Wang, Y. 2017. The dynamics of political embeddedness in China. Administrative Science Quarterly, 62(1): 67-104. 
He, B., \& Warren, M. E. 2011. Authoritarian deliberation: The deliberative turn in Chinese political development. Perspectives on Politics, 9(2): 269-289.

Henisz, W. J., \& Zelner, B. A. 2005. Legitimacy, interest group pressures, and change in emergent institutions: The case of foreign investors and host country governments. Academy of Management Review, 30(2): 361-382.

Hertog, S. 2010. Princes, brokers, and bureaucrats: Oil and the state in Saudi Arabia. Ithaca: Cornell University Press.

Hertog, S. 2013. Introduction: The role of MENA business in policy-making and political transitions. In S. Hertog, G. Luciani, \& M. Valeri (Eds), Business politics in the Middle East: 1-16. London, United Kingdom: Hurst \& Company.

Hertog, S., Luciani, G., \& Valeri, M. (Eds). 2013. Business politics in the Middle East. London, United Kingdom: Hurst \& Company.

Hubbard, B., Kirkpatrick, D. D., Kelly, K., \& Mazzetti, M. 11 March, 2018. Saudis said to use coercion and abuse to seize billions. The New York Times.

Huber, K., \& Schormair, M. J. L. 2019. Progressive and conservative firms in multistakeholder initiatives: Tracing the construction of Political CSR identities within the Accord on Fire and Building Safety in Bangladesh. Online First: Business \& Society.

Jamali, D., \& Carroll, A. 2017. Capturing advances in CSR: Developed versus developing country perspectives. Business Ethics: A European Review, 26(4): 321-325.

Jamali, D., Jain, T. Samara, G., \& Zoghbi, E. 2020. How institutions affect CSR practices in the Middle East and North Africa: A critical review. Journal of World Business, 55(5): Virtual collection.

Jamali, D., \& Karam, C. 2018. Corporate social responsibility in developing countries as an emerging field of study. International journal of Management Reviews, 20(1): 32-61.

Jamali, D., Karam, C., Yin, J., \& Soundararajan, V. 2017. CSR logics in developing countries: Translation, adaptation and stalled development. Journal of World Business, 52(3): 343359.

Jamali, D., \& Neville, B. 2011. Convergence versus divergence of CSR in developing countries: An embedded multi-layered institutional lens. Journal of Business Ethics, 102(4): 599-621.

Jebnoun, N., Kia, M., \& Kirk, M. (Eds). 2015. Modern Middle Eastern authoritarianism: Roots, ramifications, and crisis: Routledge.

Jia, N., Shi, J., \& Wang, Y. 2018. The interdependence of public and private stakeholder influence: A study of political patronage and corporate philanthropy in China. In S. Dorobantu, R. V. Aguilera, I. Luo \& F. I. Milliken (Eds), Sustainability, stakeholder governance, and corporate social responsibility, vol. 38: 69-93. Bingley, UK: Emerald Publishing.

Josua, M., \& Edel, M. 2014. To repress or not to repress - regime survival strategies in the Arab Spring. Terrorism and Political Violence, 27(2): 289-309.

Joyce, P. 2015. Environmental performance and public governance in the Gulf countries: The emergence of strategic-state capabilities. In D. Bryde, T. i. F. Rashīd \& Y. Mouzughi (Eds), Sustainable development challenges in the Arab states of the Gulf: 50-70. Berlin, Germany: Gerlach Press.

Kamasak, R., James, S. R., \& Yavuz, M. 2019. The interplay of corporate social responsibility and corporate political activity in emerging markets: The role of strategic flexibility in nonmarket strategies. Business Ethics: A European Review, 28(3): 305-320.

Kamel, H., \& Awadallah, E. 2017. The extent of voluntary corporate disclosure in the Egyptian stock exchange: Its determinants and consequences. Journal of Accounting in Emerging Economies, 7(2): 266-291.

Khanna, T., \& Palepu, K. G. 2010. Winning in emerging markets: $A$ road map for strategy and execution. Boston, MA: Harvard Business Review Press.
King, G., Pan, J., \& Roberts, M. E. 2013. How censorship in China allows government criticism but silences collective expression. American Political Science Review, 107(2): 326-343.

Kingdom of Saudi Arabia. 2015. Vision 2030. Retrieved from http://vision2030.gov.sa/en.

Knudsen, J. S., \& Brown, D. 2015. Why governments intervene: Exploring mixed motives for public policies on corporate social responsibility. Public Policy and Administration, 30(1): 51-72.

Knudsen, J. S., \& Moon, J. 2017. Visible hands: Government regulation and international business responsibility. Cambridge, UK: Cambridge University Press.

Knutsen, C. H. 2013. Democracy, state capacity, and economic growth. World Development, 43: 1-18.

Kobrin, S. J. 2009. Private political authority and public responsibility: Transnational politics, transnational firms, and human rights. Business Ethics Quarterly, 19(3): 349-374.

Kolk, A. 2016. The social responsibility of international business: From ethics and the environment to CSR and sustainable development. Journal of World Business, 51(1): 23-34.

Kolk, A., \& Lenfant, F. 2010. MNC reporting on CSR and conflict in Central Africa. Journal of Business Ethics, 93: 241-255.

Kolk, A., \& Lenfant, F. 2015a. Cross-sector collaboration, institutional gaps, and fragility: The role of social innovation partnerships in a conflict-affected region. Journal of Public Policy \& Marketing, 34(2): 287-303.

Kolk, A., \& Lenfant, F. 2015b. Partnerships for peace and development in fragile states: Identifying missing links. Academy of Management Perspectives, 29(4): 422-437.

Kolk, A., \& Lenfant, F. 2016. Hybrid business models for peace and reconciliation. Business Horizons, 59(5): 503-524.

Kolk, A., \& van Tulder, R. 2010. International business, corporate social responsibility and sustainable development. International Business Review, 19(2): 119-125.

Köllner, P., \& Kailitz, S. 2013. Comparing autocracies: Theoretical issues and empirical analyses. Democratization, 20(1): 112.

Kourula, A. 2010. Corporate Engagement with Non-governmental Organizations in Different Institutional Contexts-A Case Study of a Forest Products Company. Journal of World Business, 45(4): 395-404.

Kourula, A., Moon, J., Salles-Djelic, M.-L., \& Wickert, C. 2019. New roles of government in the governance of business conduct: Implications for management and organizational research. Organization Studies, 40(8): 1101-1123.

Krasner, S. D. 1984. Review: Approaches to the state: Alternative conceptions and historical dynamics. Comparative Politics, 16(2): 223-246.

Kropf, A. 2016. Oil export economies: New comparative perspectives on the Arab Gulf states. Berlin: Gerlach Press.

Lagoarde-Segot, T. 2011. Corporate social responsibility as a bolster for economic performance: Evidence from emerging markets. Global Business and Organizational Excellence, 31(1): 38-53.

Lawton, T., McGuire, S., \& Rajwani, T. 2013. Corporate political activity: A literature review and research agenda. International Journal of Management Reviews, 15(1): 86-105.

Levy, D., Reinecke, J., \& Manning, S. 2016. The Political Dynamics of Sustainable Coffee: Contested Value Regimes and the Transformation of Sustainability. Journal of Management Studies, 53(3): 364-401.

Li, Y., Peng, M. W., \& Macaulay, C. D. 2013. Market-political ambidexterity during institutional transitions. Strategic Organization, 11(2): 205-213.

Linz, J. J. 2000. Totalitarian and authoritarian regimes. Boulder, Colorado, London: Lynne Rienner.

Lundan, S. M. 2018. From the editor: Engaging international business scholars with public policy issues. Journal of International Business Policy, 1(1-2): 1-11.

Luo, Y., \& Zhao, H. 2013. Doing business in a transitional society. Business \& Society, 52(3): 515-549. 
Lux, S., Crook, T. R., \& Woehr, D. J. 2011. Mixing business with politics: A meta-analysis of the antecedents and outcomes of corporate political activity. Journal of Management, 37(1): 223-247.

Mann, M. 1986. The autonomous power of the state: Its origins, mechanisms, and results. In J. A. Hall (Ed.), States in history: 109-136. Oxford, New York: Basil Blackwell.

Marquis, C., \& Qian, C. 2014. Corporate Social Responsibility Reporting in China: Symbol or Substance? Organization Science, 25(1): 127-148.

Matten, D., \& Crane, A. 2005. Corporate citizenship: Toward an extended theoretical conceptualization. The Academy of Management Review, 30(1): 166-179.

Mellahi, K., Frynas, J. G., Sun, P., \& Siegel, D. 2016. A review of the nonmarket strategy literature. Journal of Management, 42(1): 143-173.

Mena, S., \& Palazzo, G. 2012. Input and output legitimacy of multi-stakeholder initiatives. Business Ethics Quarterly, 22(3): 527-556.

Migdal, J. S. 2003. State in society: Studying how states and societies transform and constitute one another. Cambridge: Cambridge University Press.

Minnee, F., Shanka, T., Taylor, R., \& Handley, B. 2013. Exploring corporate responsibility in Oman - social expectations and practice. Social Responsibility Journal, 9(2): 326-339.

Mitchell, T. 1991. The limits of the state: Beyond statist approaches and their critics. The American Political Science Review, 85(1): 77-96.

Møller, J., \& Skaaning, S.-E. 2013. Autocracies, democracies, and the violation of civil liberties. Democratization, 20(1): 82106.

Morsing, M., \& Roepstorff, A. 2015. CSR as corporate political activity: Observations on IKEA's CSR identity-image dynamics. Journal of Business Ethics, 128(2): 395-409.

Mühlberger, W. 2014. The state of Arab statehood: Reflections on failure, resilience and collapse. Tarragona: European Institute of the Mediterranean.

Nalband, N. A., \& Al-Amri, M. S. 2013. Corporate social responsibility: Perception, practices and performance of listed companies of Kingdom of Saudi Arabia. Competitiveness Review, 23(3): 284-295

Nettl, J. P. 1968. The state as a conceptual variable. World Politics, 20(4): 559-592.

Niblock, T. 2007. The political economy of Saudi Arabia. New York: Routledge.

North, D. C. 2017. Institutions, institutional change and economic performance. Cambridge, UK: Cambridge University Press.

OECD. 2013. State-owned enterprises in the Middle East and North Africa: Engines of development and competitiveness?. Paris, France: OECD.

Oetzel, J., \& Getz, K. 2012. Why and how might firms respond strategically to violent conflict? Journal of International Business Studies, 43(2): 166-186.

Orazgaliyev, S. 2018. State intervention in Kazakhstan's energy sector: Nationalisation or participation? Journal of Eurasian Studies, 9(2): 143-151.

Örtenblad, A. (Ed.). 2016. Research handbook on corporate social responsibility in context. Cheltenham, UK, Northampton, MA: Edward Elgar Publishing.

Palazzo, G., \& Scherer, A. G. 2006. Corporate legitimacy as deliberation: A communicative framework. Journal of Business Ethics, 66(1): 71-88.

Peng, M. W., \& Luo, Y. 2000. Managerial ties and firm performance in a transition economy: The nature of a micromacro link. Academy of Management lournal, 43(3): 486-501.

Perlmutter, A. 1981. Modern authoritarianism: A comparative institutional analysis. New Haven, Connecticut: Yale University Press.

Peters, A. M., \& Moore, P. W. 2009. Beyond boom and bust: External rents, durable authoritarianism, and institutional adaptation in the Hashemite Kingdom of Jordan. Studies in Comparative International Development, 44(3): 256-285.

Pisani, N., Kourula, A., Kolk, A., \& Meijer, R. 2017. How global is international CSR research? Insights and recommendations from a systematic review. Journal of World Business, 52(5): 591-614.

Rajwani, T., \& Liedong, T. A. 2015. Political activity and firm performance within nonmarket research: A review and international comparative assessment. Journal of World Business, 50(2): 273-283.

Rehbein, K., \& Schuler, D. A. 2015. Linking corporate community programs and political strategies. Business \& Society, 54(6): 794-821.

Rivlin, P. 2009. Arab economies in the twenty-first century. Cambridge, UK: Cambridge University Press.

Rudy, B. C., \& Johnson, A. F. 2019. The chief political officer: CEO characteristics and firm investment in corporate political activity. Business \& Society, 58(3): 612-643.

Ruggie, J. G. 2018. Multinationals as global institution: Power, authority and relative autonomy. Regulation \& Governance, 12(3): 317-333.

Sassoon, J. 2016. Anatomy of authoritarianism in the Arab republics. Cambridge, UK: Cambridge University Press.

Savoia, A., \& Sen, K. 2015. Measurement, evolution, determinants, and consequences of state capacity: a review of recent research. Journal of Economic Surveys, 29(3): 441-458.

Sawani, Y. M. 2014. Arabs and democracy: An analysis of the findings of the survey of Arab public opinion towards democracy. Contemporary Arab Affairs, 7(3): 351-362.

Scherer, A. G., \& Palazzo, G. 2007. Toward a political conception of corporate responsibility: business and society seen from a Habermasian perspective. Academy of Management Review, 32(4): 1096-1120.

Scherer, A. G. \& Palazzo, G. 2011. The new political role of business in a globalized world: A review of a new perspective on CSR and its implications for the firm, governance, and democracy. Journal of Management Studies, 48(4): 899-931.

Scherer, A. G., Palazzo, G., \& Matten, D. 2014. The business firm as a political actor: A new theory of the firm for a globalized world. Business \& Society, 53(2): 143-156.

Scherer, A. G., Palazzo, G., \& Seidl, D. 2013. Managing legitimacy in complex and heterogeneous environments: Sustainable development in a globalized world. Journal of Management Studies, 50(2): 259-284.

Scherer, A. G., Rasche, A., Palazzo, G., \& Spicer, A. 2016. Managing for political corporate social responsibility: New challenges and directions for PCSR 2.0. Journal of Management Studies, 53(3): 273-298.

Schlumberger, O. 2007. Arab authoritarianism: Debating the dynamics and durability of nondemocratic regimes. In $\mathrm{O}$. Schlumberger (Ed.), Debating Arab authoritarianism. Dynamics and durability in nondemocratic regimes: 1-18. Stanford, CA: Stanford University Press.

Schneider, A., \& Scherer, A. G. 2019. State governance beyond the 'shadow of hierarchy': A social mechanisms perspective on governmental CSR policies. Organization Studies, 40(8): 11471168.

Schrempf-Stirling, J. 2018. State power: Rethinking the role of the state in political corporate social responsibility. Journal of Business Ethics, 150(1): 1-14.

Schuler, D. A., Rehbein, K., \& Green, C. D. 2019. Is corporate political activity a field? Business \& Society, 58(7): 1376-1405.

Schwarz, R. 2008. The political economy of state-formation in the Arab Middle East: Rentier states, economic reform, and democratization. Review of International Political Economy, 15(4): 599-621.

Sidki Darendeli, I., \& Hill, T. L. 2016. Uncovering the complex relationships between political risk and MNE firm legitimacy: Insights from Libya. Journal of International Business Studies, 47(1): 68-92. 
Sprenger, C. 2008. State-owned enterprises in Russia: Presentation at the OECD roundtable on corporate governance of SOEs. Moscow.

Suchman, M. C. 1995. Managing legitimacy: Strategic and institutional approaches. The Academy of Management Review, 20(3): 571.

Svolik, M. W. 2012. The politics of authoritarian rule. New York: Cambridge University Press.

Tilly, C. 2003. Inequality, democratization, and de-democratization. Sociological Theory, 21(21): 37-43.

Tilly, C. 2007. Democracy. Cambridge, UK: Cambridge University Press.

Transparency International. 2018. Corruption Perception Index. Retrieved from https://www.transparency.de/cpi/. Accessed 2019, October 11.

Vachani, S., Doh, J. P., \& Teegen, H. 2009. NGOs' influence on MNEs' social development strategies in varying institutional contexts: A transaction cost perspective. International Business Review, 18(5): 446-456.

Walk Free Foundation. 2018. Global Slavery Index 2018. Perth: The Minderoo Foundation Pty Ltd.

Wang, H., Tong, L., Takeuchi, R., \& George, G. 2016. Corporate social responsibility: An overview and new research directions: Thematic issue on corporate social responsibility. Academy of Management Journal, 59(2): 534-544.

Westermann-Behaylo, M. K., Rehbein, K., \& Fort, T. 2015. Enhancing the concept of corporate diplomacy: Encompassing political corporate social responsibility, international relations, and peace through commerce. Academy of Management Perspectives, 29(4): 387-404.

Whitley, R. 1999. Divergent capitalisms: The social structuring and change of business systems. Oxford, New York: Oxford University Press.

Wickert, C. 2014. "Political" Corporate Social Responsibility in Small- and Medium-Sized Enterprises: A Conceptual Framework. Business \& Society, 55(6): 792-824.

Wiig, A., \& Kolstad, I. 2010. Multinational corporations and host country institutions: A case study of CSR activities in Angola. International Business Review, 19(2): 178-190.

Witt, M. A., \& Redding, G. 2014. China: Authoritarian capitalism. In M. A. Witt \& G. Redding (Eds), The Oxford Handbook of Asian business systems: 11-32 (1st ed.). Oxford: Oxford University Press.

Wood, G., \& Wright, M. 2015. Corporations and new statism: Trends and research priorities. Academy of Management Perspectives, 29(2): 271-286.

Wrona, T., \& Sinzig, C. 2018. Nonmarket strategy research: Systematic literature review and future directions. Journal of Business Economics, 88(2): 253-317.

Zhao, M., Park, S. H., \& Zhou, N. 2014. MNC strategy and social adaptation in emerging markets. Journal of International Business Studies, 45(7): 842-861.
Zovighian, D. 2013. The politics of "good governance" in Mubarak's Egypt: Western donors and SME politics under authoritarian rule. In S. Hertog, G. Luciani, \& M. Valeri (Eds), Business politics in the Middle East: 183-209. London, United Kingdom: Hurst \& Company.

\section{ABOUT THE AUTHOR}

Anna-Lena Maier is a research associate at the Chair of Business Ethics and Management at the University of Hamburg. Her prior professional experiences include providing advisory services to German firms seeking to enter Middle Eastern markets. Her research interests are political strategies of multinational enterprises, business-government relations in autocracies, and ethics of qualitative extreme context research. She holds master's degrees in Peace Research and Security Policy as well as political Science from the Institute for Peace Research and Security Policy Hamburg and the University of Hamburg, respectively.

Open Access This article is licensed under a Creative Commons Attribution 4.0 International License, which permits use, sharing, adaptation, distribution and reproduction in any medium or format, as long as you give appropriate credit to the original author(s) and the source, provide a link to the Creative Commons licence, and indicate if changes were made. The images or other third party material in this article are included in the article's Creative Commons licence, unless indicated otherwise in a credit line to the material. If material is not included in the article's Creative Commons licence and your intended use is not permitted by statutory regulation or exceeds the permitted use, you will need to obtain permission directly from the copyright holder. To view a copy of this licence, visit http://creativecommons.org/licenses/by/4.0/.

Publisher's Note Springer Nature remains neutral with regard to jurisdictional claims in published maps and institutional affiliations.

Accepted by Rob van Tulder, Area Editor, 17 November 2020. This article has been with the author for three revisions. 